\title{
Should fetal growth be a matter of concern in isolated single umbilical artery?
}

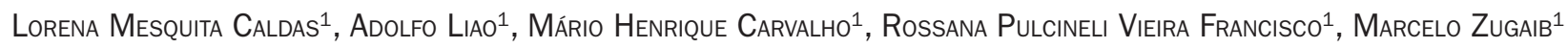

Study conducted at Hospital das Clínicas, São Paulo University Medical School, São Paulo, SP

Article received: 04/04/13 Accepted for publication: 08/30/13

Correspondence: Departamento de Ginecologia e Obstetrícia

Hospital das Clínicas

Faculdade de Medicina da USP Address: Av. Dr. Enéas de Carvalho Aguiar, $255-10^{\circ}$. Andar, cj. 10037 ZIP Code: 05403-000 São Paulo - SP - Brazil Phone: +55 11 2661-6209 Fax $+55112661-8183$ liao@usp.br

http://dx.doi.org/10.1590/1806-9282.60.02.009 Conflict of interest: none

\section{SUMmARY}

Objective: To examine birth weight in pregnancies with isolated single umbilical artery (ISUA).

Methods: Case control study with retrospective review of 131 singleton pregnancies with isolated single umbilical artery diagnosed before birth. Control group consisted of 730 singleton pregnancies recruited prospectively, that had histological confirmation of a 3 vessels cord. Pregnancies were classified as uncomplicated or high-risk according to the presence of diseases that increase the risk of placental insufficiency during pregnancy. Mean birth weight and frequency of low birth weight $(<2.500 \mathrm{~g})$, very low birth weight $(<1.500 \mathrm{~g})$ and fetal growth restriction below the $5^{\text {th }}$ and $10^{\text {th }}$ centiles were compared between groups.

Results: Mean birth weight difference between ISUA $(\mathrm{n}=131,2840 \pm 701 \mathrm{~g})$ and control $(\mathrm{n}=730,2.983 \pm 671 \mathrm{~g})$ pregnancies was $143 \mathrm{~g}(95 \% \mathrm{CI}=17-269 ; \mathrm{p}=0.04)$ and birth weight below the $5^{\text {th }}$ centile was significantly more common in ISUA group [28/131 (21.4\%) versus 99/730 (13.6\%), $\mathrm{p}=0.02]$. When only uncomplicated pregnancies were considered in both groups, no birth weight differences were observed. Amongst high-risk subgroups, birth weight below the $5^{\text {th }}$ centile remained significantly more common in ISUA compared to control pregnancies [10/35 (28.6\%) versus 53/377 (14.1\%), $\mathrm{p}=0.04]$.

Conclusion: Isolated single umbilical artery does not increase the risk of fetal growth restriction in uncomplicated singleton pregnancies.

Key words: single umbilical artery, fetal growth retardation, birth weight, ultrasonography.

\section{INTRODUCTION}

Normally, the human umbilical cord contains two arteries that transport blood from the fetus to the placenta, and oxygenated blood returns to the fetus via a single umbilical vein. However, a single umbilical artery (SUA) can be diagnosed antenatally by ultrasound in up to $2 \%$ of pregnancies ${ }^{1}$ and, when it is associated with other fetal structural defects, there is an increased risk of chromosomal abnormalities and adverse pregnancy outcome. ${ }^{2}$

Nevertheless, the clinical relevance of an isolated SUA remains controversial. Compensatory mechanisms allow increase in blood flow through the single artery in order to meet the demands of fetal growth and development throughout pregnancy. ${ }^{3}$ Although several studies have reported diminished fetal growth in these pregnancies, ${ }^{4-12}$ others have not shown differences. ${ }^{13-15}$ These contradictory findings may be attributed to diverse methodological differences in the published literature.

The present study examines birth weight in pregnancies with isolated single umbilical artery diagnosed antenatally in a tertiary care teaching hospital.

\section{Methods}

This was a case-control study involving singleton pregnancies that attended the Department of Obstetrics and Gynecology at the São Paulo University Medical School Hospital, a tertiary care teaching medical facility. The study protocol was approved by the hospital's ethics committee $(0685 / 10)$. 


\section{Isolated single umbilical artery study group}

A computer database search was performed to retrospectively identify all singleton pregnancies in which an isolated single umbilical artery (ISUA) was diagnosed antenatally by ultrasound scan between 1998 and 2010. The diagnosis was based on the visualization of two vessels in a cross section view of a free loop of umbilical cord in a fetus without structural abnormalities. All cases were confirmed after birth by clinical and/or pathological examination of the cord. Live born infants with no phenotypic features of a chromosomal defect were assumed to be euploid.

\section{Control group}

It was based on a cohort of 759 unselected singleton pregnancies prospectively examined between 2007 and 2009 - that had already been included in a previous publication $^{1}$. In this group, a three vessels cord was confirmed by two ultrasound examinations (carried out at 11-13 weeks and 17-24 weeks) and placental examination after delivery. Seven hundred and thirty (96.2\%) women delivered phenotypically normal live born infants.

\section{Data collection}

Hospital records were reviewed for pregnancy and outcome information. Women who delivered their babies in other hospitals were contacted by telephone.

Maternal characteristics including age, ethnic group and presence of clinical or obstetrical complications were recorded. Pregnancies were classified as uncomplicated or high-risk according to the presence of diseases that increase the risk of placental insufficiency during pregnancy: hypertension, cardiomyopathy, asthma, diabetes, hemoglobinopathy, thrombophilia, thromboembolism, cirrhosis, kidney failure or auto immune diseases.

Gestational age was calculated based on the first day of the last menstrual period when available and confirmed by early ultrasound examination. When menstrual dates were uncertain, or there was discrepancy greater than 7 days between clinical and ultrasound dates, gestational age was established according to the earliest ultrasound scan findings.

Birth weight was examined according to previously published reference values ${ }^{16}$ and primary outcomes were defined as birth weight below the $5^{\text {th }}$ and $10^{\text {th }}$ centiles.

\section{Statistical analysis}

All data was entered in an Excel spreadsheet (Microsoft Corporation, USA). Maternal demographics and frequency of birth weight below the $5^{\text {th }}$ and $10^{\text {th }}$ centiles were com- pared between ISUA and control groups using unpaired Student $t$ test and chi square tests or Fisher's exact test, when appropriate. Statistical calculations were performed using Statsdirect (StatsDirect Ltd, UK). Significance level was set as 0.05 .

\section{Results}

The database search identified 134 singleton pregnancies in which an isolated single umbilical artery was diagnosed prenatally by ultrasound. Mean gestational age at diagnosis was $25.1 \pm 5.8$ weeks and 18 (13.4\%) cases were referred before 20 weeks. 131 (97.8\%) pregnancies resulted in live births, and the diagnosis of ISUA was confirmed in all cases.

No differences were observed regarding maternal age, proportion of white women and gestational age at delivery between ISUA and control groups. Nevertheless, complications were observed significantly more often in control pregnancies $(377 / 759,49.7 \%)$ compared to the ISUA group $(35 / 134,26.1 \%, \mathrm{p}<0.001$, table 1$)$.

TABLE 1 Characteristics and perinatal outcome in isolated single umbilical artery and control pregnancies.

\begin{tabular}{|c|c|c|c|}
\hline & $\begin{array}{l}\text { study } \\
\text { group }\end{array}$ & $\begin{array}{l}\text { control } \\
\text { group }\end{array}$ & $\mathbf{P}^{*}$ \\
\hline$n$ & 134 & 759 & \\
\hline Maternal age, years (SD) & $30.8(6.7)$ & $30.3(6.6)$ & 0.41 \\
\hline White, n (\%) & $78(58.2)$ & $400(52.7)$ & 0.28 \\
\hline Complicationsa ${ }^{\mathrm{a}}$ n (\%) & $35(26.1)$ & $377(49.7)$ & $<0.001$ \\
\hline hypertension & $16(11.9)$ & $260(34.3)$ & \\
\hline cardiomyopathy & $9(6.7)$ & $32(4.2)$ & \\
\hline anemia & 0 & $21(2.8)$ & \\
\hline diabetes & $6(4.5)$ & $17(2.2)$ & \\
\hline autoimmune disease & $1(0.7)$ & $39(5.1)$ & \\
\hline thrombophilia & $3(2.2)$ & $26(3.4)$ & \\
\hline \multicolumn{4}{|l|}{ Outcome, n (\%) } \\
\hline stillbirth & $3(2.2)$ & $29(3.8)$ & 0.46 \\
\hline live birth & $131(98.5)$ & $730(96.2)$ & \\
\hline Gestational age at delivery, weeks (SD) & $37.6(2.3)$ & $37.9(2.3)$ & 0.09 \\
\hline$<34$ weeks, n (\%) & $7(5.3)$ & $43(5.9)$ & $>0.99$ \\
\hline <37 weeks, n (\%) & $31(23.7)$ & $144(19.7)$ & 0.29 \\
\hline
\end{tabular}

GA: gestational age at delivery, n: number of cases, SD: standard deviation.

*Mann-Whitney $U$ test or chi $^{2}$ test/Fisher's exact test.

a defined in the present study as the occurrence of diseases that increase the risk of placental in sufficiency during pregnancy.

Overall, significant differences were observed between ISUA and control pregnancies regarding mean birth weight (ISUA: $2.840 \pm 701 \mathrm{~g}$, control: $2.983 \pm 671 \mathrm{~g}$, mean difference $=143 \mathrm{~g}$, 95\% CI=17-269, $\mathrm{p}=0.04$, figure 1 ) and birth weight below the $5^{\text {th }}$ centile [ISUA: $28 / 131(21.4 \%)$, control: 99/730 (13.6\%), 


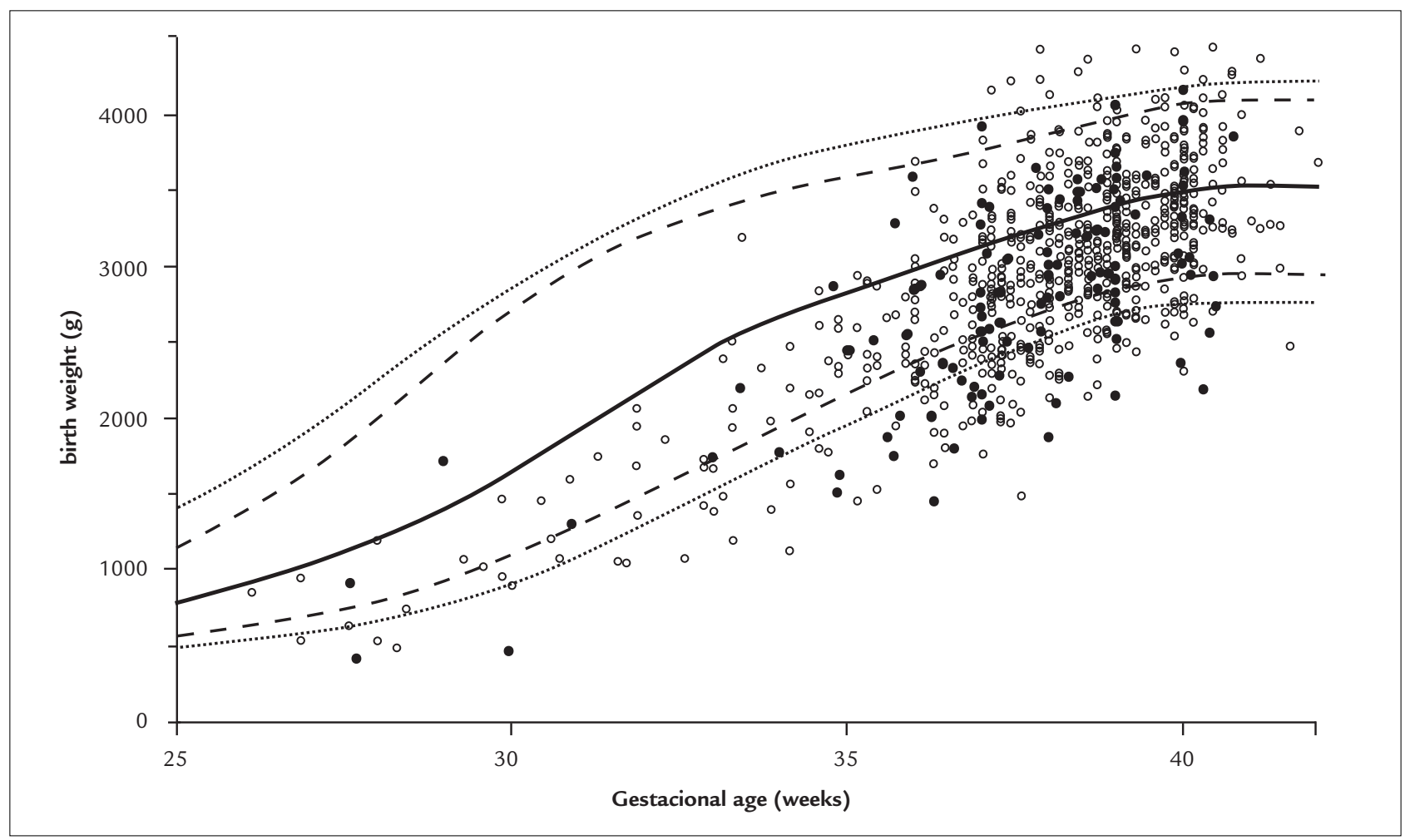

FIGURE 1 Scatter plot of birth weight according to gestational age at delivery. Open circles: control group ( $\mathrm{n}=730$ ), full circles: isolated single umbilical artery $(\mathrm{n}=131)$, continuous line: $50^{\text {th }}$ percentile, dashed lines: $10^{\text {th }}$ and $90^{\text {th }}$ percentiles, dotted lines: $5^{\text {th }}$ and $95^{\text {th }}$ percentiles. ${ }^{16}$

$\mathrm{p}=0.02$, table 2]. However, when only uncomplicated pregnancies were considered in both groups, no birth weight differences were observed. Amongst high-risk subgroups, birth weight below the $5^{\text {th }}$ centile remained significantly more common in ISUA compared to control pregnancies [10/35 (28.6\%) versus 53/377 (14.1\%), $\mathrm{p}=0.04]$.

\section{Discussion}

Several studies have previously shown the association between single umbilical artery and less fetal growth. Based on these findings, some authors have recommended that fetal growth should be monitored throughout pregnancy after prenatal diagnosis of a single umbilical artery. ${ }^{7-9,11,12}$ As a matter of fact, throughout the study period, our management protocol for pregnancies diagnosed with ISUA included serial follow up fetal growth scans. And when fetal growth restriction was diagnosed additional fetal well being tests were performed. Our current findings suggest that close fetal growth follow up is only necessary when ISUA is associated with the occurrence of maternal disease or pregnancy complication.

Moreover, gestational age at delivery and the rates of preterm delivery (before 34 and 37 weeks) were not statistically different between ISUA and control pregnan-

\section{TABLE 2 Birth weight in isolated single umbilical artery and} control pregnancies

\begin{tabular}{|c|c|c|c|}
\hline & Study group & Control group & $\mathbf{P}^{*}$ \\
\hline $\mathrm{n}$ & 131 & 730 & \\
\hline Birth weight, grams (SD) & $2840(701)$ & $2983(671)$ & 0.04 \\
\hline < $1500 \mathrm{~g}, \mathrm{n}(\%)$ & $5(3.8)$ & $28(3.8)$ & 0.99 \\
\hline < $2500 \mathrm{~g}, \mathrm{n}(\%)$ & $34(26.0)$ & $148(20.3)$ & 0.18 \\
\hline Birth weight $<5^{\text {th }}$ centile, $n(\%)$ & $28 / 131(21.4)$ & $99 / 730(13.6)$ & 0.02 \\
\hline $\mathrm{GA}<34$ weeks & $2 / 28(7.1)$ & $12 / 99(12.1)$ & 0.73 \\
\hline $\mathrm{GA}<37$ weeks & $13 / 28(46.4)$ & $34 / 99(34.3)$ & 0.24 \\
\hline Birth weight $<10^{\text {th }}$ centile, $\mathrm{n}(\%)$ & $40 / 131(30.5)$ & $169 / 730(23.2)$ & 0.07 \\
\hline GA $<34$ weeks & $3 / 40(7.5)$ & $19 / 169(11.2)$ & 0.77 \\
\hline $\mathrm{GA}<37$ weeks & $18 / 40(45)$ & $56 / 169(33.1)$ & 0.16 \\
\hline \multicolumn{4}{|l|}{ Uncomplicated pregnancies } \\
\hline Birth weight, grams (SD) & $2927(704)$ & $3058(642)$ & 0.13 \\
\hline Birth weight $<5^{\text {th }}$ centile, $n(\%)$ & $18 / 96(18.8)$ & $46 / 353(13.0)$ & 0.21 \\
\hline Birth weight $<10^{\text {th }}$ centile, $\mathrm{n}(\%)$ & $26 / 96(27.1)$ & $72 / 353(20.4)$ & 0.21 \\
\hline \multicolumn{4}{|l|}{ High-risk pregnancies ${ }^{\mathrm{a}}$} \\
\hline Birth weight, grams (SD) & $2601(647)$ & $2912(690)$ & 0.01 \\
\hline Birth weight $<5^{\text {th }}$ centile, $n(\%)$ & $10 / 35(28.6)$ & $53 / 377(14.1)$ & 0.04 \\
\hline Birth weight $<10^{\text {th }}$ centile, $\mathrm{n}(\%)$ & $14 / 35(40.0)$ & $97 / 377(25.7)$ & 0.11 \\
\hline
\end{tabular}

GA: gestational age at delivery, $\mathrm{n}$ : number of cases, SD: standard deviation.

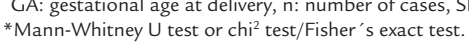

" a defined in the present study as the occurrence of diseases that increase the risk of placental insufficiency during pregnancy. 
cies. This finding suggests that prenatal diagnosis of single umbilical artery does not prompt anticipation of delivery, nor adds additional clinically relevant morbidity besides fetal growth deviation.

As a matter of fact, Wiegand et al. ${ }^{17}$ evaluated fetal growth by repeated ultrasound examinations in 138 pregnancies following the diagnosis of ISUA. Intrauterine growth restriction was observed in 3\% of the cases and the authors concluded that the risk of growth impairment is not different from the rest of their population.

Additional clinical relevance of ISUA was also evaluated after birth in a prospective cohort by Chetty-John et al. ${ }^{10}$ No significant differences in physical growth and neurological development were observed. There was also no evidence of increased need for admission to neonatal intensive care units (Bombrys et al.). ${ }^{14}$

In fetuses with two vessels cord, compensatory mechanisms are in place to allow the single artery to meet the demands for fetal development during late pregnancy. One of these mechanisms is an increase of the arterial diameter. Sepulveda et al. have described that in fetuses with ISUA, the diameter of the umbilical artery was greater than $50 \%$ of the umbilical vein, resulting in an umbilical vein to umbilical artery ratio $\leq 2 .{ }^{3}$

Additional adaptive mechanism was suggested by the observation that birth weight centile correlates with both umbilical vein to artery perimeter ratio and impedance to flow in the uterine arteries. ${ }^{18}$ The authors hypothesized that fetal growth restriction associated with ISUA is not based on deficient trophoblast invasion but could be due to changes in the maternal uterine circulation and morphological characteristics of the vessels in the umbilical cord.

Moreover, a recent publication showed that birth weight was lower in left side absent umbilical artery singleton pregnancies compared to controls, but not in right side absent artery cases. ${ }^{19}$ The authors suggest that differences between left and right side vascular anatomy possibly also play a role in single umbilical artery fetal adaptive mechanisms.

Table 3 summarizes the studies that have evaluated the association between ISUA and low birth weight. Eleven series are based on cases diagnosed prenatally and significant differences in birth weight were demonstrated in four out of six studies that included control groups. $., 7,11,13-15,18,20-23$

On the other hand, all post-natal studies have shown that birth weight is significantly lower in ISUA pregnancies compared to control pregnancies. ${ }^{5,9,10,12}$ This is possibly related to the fact that these are the studies with greater sample size. Moreover, since ISUA was not diagnosed before birth, these pregnancies were more likely to have reached full term despite the presence of growth deviation.

Overall, twelve of these studies have made statements regarding the need for fetal growth follow up scans in pregnancies with ISUA: nine recommended routine scans and three considered them unnecessary (table 3 ).

The present study demonstrates that the likelihood of giving birth to a growth restricted neonate is not increased in uncomplicated pregnancies with an isolated single umbilical artery. However, in complicated pregnancies, this likelihood seems increased. Nevertheless, due to the limited sample size, and possible additional confounding factors that have not been addressed, this finding needs to be further evaluated.

Due to the tertiary nature of our hospital, our data presents an opportunity to examine the effect of ISUA on fetal growth in uncomplicated pregnancies, and a considerable number of cases with preexisting maternal medical and/or pregnancy complications. In the latter subgroup, the odds for fetal growth restriction seem enhanced and specific antenatal follow up and surveillance is advisable after the diagnosis of an ISUA. To the best of our knowledge, this is the first paper that presents specific data on the impact of ISUA on birth weight in high-risk pregnancies.

Nevertheless, due to the lack of robust prospective antenatal series, the true magnitude and long term impact of an ISUA on perinatal results and posterior childhood development are still not clear in these pregnancies, especially in otherwise uncomplicated ones. Prospective collaborative collection of data may help determine the best antenatal management protocols in these cases.

\section{Conclusion}

Isolated single umbilical artery does not increase the risk of fetal growth restriction in uncomplicated singleton pregnancies.

\section{Resumo}

Artéria umbilical única isolada e restrição do crescimento fetal

Objetivo: Examinar a frequência de peso ao nascer abaixo dos percentis 5 e 10, em gestações únicas com artéria umbilical única isolada (AUUI), de acordo com a presença de complicações maternas.

Métodos: Estudo caso-controle. De acordo com a presença de doenças maternas prévias à gestação, ou ocorrência de complicações obstétricas, as gestações foram classificadas em "não complicadas" ou de "alto risco". As 
TABLE 3 Studies evaluating the association between isolated single umbilical artery and low birth weight

\begin{tabular}{|c|c|c|c|c|c|c|}
\hline Study & Design & $\begin{array}{l}\text { Number of } \\
\text { cases }\end{array}$ & Diagnosis & LBW criteria & Frequency (\% ) & $\begin{array}{l}\text { Recommendation } \\
\text { for fetal growth } \\
\text { monitoring }\end{array}$ \\
\hline $\begin{array}{l}\text { Bryan \& Kohler } \\
1974^{24}\end{array}$ & prospective & 113 & PN examination & $<10^{\text {th }}$ centile & 22.1 & NS \\
\hline Heifetz $1984^{4}$ & $\begin{array}{l}\text { Retrospective } \\
\text { case-control }\end{array}$ & 69 & Autopsy & SGA & $\begin{array}{l}43.5 \text { versus } 23.8 \\
(p<0.01)\end{array}$ & NS \\
\hline Lilja $1991^{5}$ & $\begin{array}{l}\text { Retrospective } \\
\text { case-control }\end{array}$ & 1674 & PN examination & $<2500 \mathrm{~g}$ & $\begin{array}{l}11.4 \text { versus } 3.6 \\
(p<0.0001)\end{array}$ & NS \\
\hline Jones et al. $1993^{6}$ & $\begin{array}{l}\text { Retrospective } \\
\text { case-control }\end{array}$ & 37 & $\begin{array}{l}\text { US + PN } \\
\text { confirmation }\end{array}$ & Birth weight & $\begin{array}{l}2750 \mathrm{~g} \text { versus } 3170 \mathrm{~g} \\
(\mathrm{p}<0.01)\end{array}$ & NS \\
\hline $\begin{array}{l}\text { Catanzarite et al. } \\
1995^{20}\end{array}$ & Retrospective & 38 & $\begin{array}{l}\text { US + PN } \\
\text { confirmation }\end{array}$ & $<10^{\text {th }}$ centile & 18.0 & Yes \\
\hline Parilla et al. $1995^{21}$ & Retrospective & 50 & $\begin{array}{l}\text { US + PN } \\
\text { confirmation }\end{array}$ & $<2500 \mathrm{~g}$ & 12.0 & No \\
\hline Geipel et al. $2000^{22}$ & Retrospective & 59 & $\begin{array}{l}\text { US + PN } \\
\text { confirmation }\end{array}$ & $<10^{\text {th }}$ centile & 10.2 & NS \\
\hline $\begin{array}{l}\text { Rinehart et al. } \\
2000^{23}\end{array}$ & Retrospective & 6 & US & NS & 50.0 & Yes \\
\hline Gornall et al. $2003^{7}$ & $\begin{array}{l}\text { Retrospective } \\
\text { case-control }\end{array}$ & 83 & $\begin{array}{l}\text { US + PN } \\
\text { confirmation }\end{array}$ & $<10^{\text {th }}$ centile & $\begin{array}{l}22.0 \text { versus } 12.0 \\
(p<0.007)\end{array}$ & Yes \\
\hline $\begin{array}{l}\text { Predanic et al. } \\
2005^{13}\end{array}$ & $\begin{array}{l}\text { Retrospective } \\
\text { case-control }\end{array}$ & 84 & $\begin{array}{l}\text { US + PN } \\
\text { confirmation }\end{array}$ & $<10^{\text {th }}$ centile & $\begin{array}{l}7.1 \text { versus } 4.8 \\
(p=0.75)\end{array}$ & No \\
\hline Mu et al. $2008^{8}$ & $\begin{array}{l}\text { Retrospective } \\
\text { case-control }\end{array}$ & 14 & $\mathrm{PN}$ & $<10^{\text {th }}$ centile & $\begin{array}{l}35.7 \text { versus } 3.6 \\
(p=0.01)\end{array}$ & Yes \\
\hline $\begin{array}{l}\text { Bombrys } \\
\text { et al. } 2008^{14}\end{array}$ & $\begin{array}{l}\text { Retrospective } \\
\text { case-control }\end{array}$ & 255 & $\begin{array}{l}\text { US + PN } \\
\text { confirmation }\end{array}$ & $<10^{\text {th }}$ centile & $\begin{array}{l}13.7 \text { versus } 13.1 \\
(p=0.84)\end{array}$ & No \\
\hline $\begin{array}{l}\text { Burshtein et al. } \\
2009^{9}\end{array}$ & $\begin{array}{l}\text { Retrospective } \\
\text { population } \\
\text { based }\end{array}$ & 243 & PN & NS & $\begin{array}{l}9.5 \text { versus } 1.9 \\
(p<0.001) \\
\text { OR } 5.4(95 \% \text { Cl } 3.5-8.4)\end{array}$ & Yes \\
\hline Bugatto et al. $2010^{18}$ & NS & 60 & $\begin{array}{l}\text { US + PN } \\
\text { confirmation }\end{array}$ & $<10^{\text {th }}$ centile & 30.0 & Yes \\
\hline $\begin{array}{l}\text { Chetty-John et al. } \\
2010^{10}\end{array}$ & $\begin{array}{l}\text { Prospective } \\
\text { cohort }\end{array}$ & 263 & $\mathrm{PN}$ & birth weight & $\begin{array}{l}3.1 \mathrm{~kg} \text { versus } 3.2 \mathrm{~kg} \\
(\mathrm{p}<0.0001)\end{array}$ & NS \\
\hline Horton et al. $2010^{15}$ & $\begin{array}{l}\text { Retrospective } \\
\text { case-control }\end{array}$ & 68 & $\begin{array}{l}\text { US + PN } \\
\text { confirmation }\end{array}$ & $<10^{\text {th }}$ centile & $\begin{array}{l}17.6 \text { versus } 8.8 \\
(p=0.06)\end{array}$ & Yes \\
\hline Hua et al. $2010^{11}$ & $\begin{array}{l}\text { Retrospective } \\
\text { cohort }\end{array}$ & 281 & $\begin{array}{l}\text { US + PN } \\
\text { confirmation }\end{array}$ & $<10^{\text {th }}$ centile & $\begin{array}{l}\text { OR } 1.9 \\
(95 \% \mathrm{Cl}: 1.4-2.5)\end{array}$ & Yes \\
\hline $\begin{array}{l}\text { Murphy-Kaulbeck et } \\
\text { al. } 2010^{12}\end{array}$ & $\begin{array}{l}\text { Retrospective } \\
\text { population } \\
\text { based-cohort }\end{array}$ & 725 & $\mathrm{PN}$ & $\begin{array}{l}<3^{\text {rd }} \text { centile } \\
<10^{\text {th }} \text { centile }\end{array}$ & $\begin{array}{l}11.1 \text { versus } 3.7 \\
\text { OR } 2.5(95 \% \mathrm{Cl} 1.9-3.2) \\
25.0 \text { versus } 10.9 \\
\text { OR } 2.2(95 \% \mathrm{Cl} 1.8-2.7)\end{array}$ & Yes \\
\hline Present study & $\begin{array}{l}\text { Retrospective } \\
\text { cases and } \\
\text { prospective } \\
\text { controls }\end{array}$ & 131 & $\begin{array}{l}\text { US + PN } \\
\text { confirmation }\end{array}$ & $\begin{array}{l}<5^{\text {th }} \text { centile } \\
<10^{\text {th }} \text { centile }\end{array}$ & $\begin{array}{l}21.4 \text { versus } 13.6(p=0.03) \\
30.5 \text { versus } 23.2(p=0.06)\end{array}$ & $\begin{array}{l}\text { Yes (high-risk } \\
\text { pregnancies only) }\end{array}$ \\
\hline
\end{tabular}

Cl: confidence interval, EFW: estimated fetal weight, LBW: low birth weight, NS: not stated, OR: odds ratio, PN: post natal, SGA: small for gestation age US: ultrasound. 
frequências de peso ao nascer abaixo dos percentis 5 e 10 foram comparadas entre os subgrupos.

Resultados: $O$ peso ao nascer foi significativamente menor em gestações com AUUI ( $n=134,2840 \pm 701 \mathrm{~g})$ quando comparado com o grupo controle $(n=730,2983 \pm$ $671 \mathrm{~g}, \mathrm{p}=0,04$; média da diferença $=143 \mathrm{~g}$, IC 95\% = 17-269). Em gestações de alto risco, peso ao nascer abaixo do $5^{\circ}$ percentil foi significativamente mais frequente no subgrupo com AUUI [10/35 (28,6\%) versus 53/377 $(14,1 \%), p=0,04$; razão de chances $=2.45($ IC $95 \%=1,11$ $5,38)]$; não foi observada diferença em relação ao peso abaixo do $10^{\circ}$ percentil $(p=0,11)$. Em gestações não complicadas, não foram observadas diferenças na frequência de peso ao nascer abaixo do $5^{\circ}$ e $10^{\circ}$ percentis entre os subgrupos com AUUI e cordão com 3 vasos ( $p=0,21)$.

Conclusão: Em gestações de alto risco, a frequência de peso ao nascer abaixo do percentil 5 é significativamente aumentada.

Unitermos: artéria umbilical única, retardo do crescimento intrauterino, peso ao nascer, ultrassonografia.

\section{RefEREnces}

1. Lamberty CO, Burlacchini de Carvalho MH, Miguelez J, Liao AW, Zugaib M. Ultrasound detection rate of single umbilical artery in the first trimester of pregnancy. Prenatal Diagnosis. 2011;31(9):865-8

2. Rembouskos G, Cicero S, Longo D, Sacchini C, Nicolaides KH. Single umbilical artery at 11-14 weeks' gestation: relation to chromosomal defects. Ultrasound Obstet Gynecol. 2003;22(6):567-70.

3. Sepulveda W, Peek MJ, Hassan J, Hollingsworth J. Umbilical vein to artery ratio in fetuses with single umbilical artery. Ultrasound Obstet Gynecol. 1996;8(1):23-6.

4. Heifetz SA. Single umbilical artery. A statistical analysis of 237 autopsy cases and review of the literature. Perspect Pediatr Pathol. 1984;8(4):345-78.

5. Lilja M. Infants with single umbilical artery studied in a national registry. General epidemiological characteristics. Paediatr Perinat Epidemiol 1991;5(1):27-36

6. Jones TB, Sorokin Y, Bhatia R, Zador IE, Bottoms SF. Single umbilical artery: accurate diagnosis? Am J Obstet Gynecol. 1993;169(3):538-40.

7. Gornall AS, Kurinczuk JJ, Konje JC. Antenatal detection of a single umbilical artery: does it matter? Prenat Diagn. 2003;23(2):117-23.
8. Mu SC, Lin CH, Chen YL, Sung TC, Bai CH, Jow GM. The perinatal outcomes of asymptomatic isolated single umbilical artery in full-term neonates. Pediatr Neonatol. 2008;49(6):230-3.

9. Burshtein S, Levy A, Holcberg G, Zlotnik A, Sheiner E. Is single umbilical artery an independent risk factor for perinatal mortality? Arch Gynecol Obstet. 2011;283(2):191-4.

10. Chetty-John S, Zhang J, Chen Z, Albert P, Sun L, Klebanoff M, et al. Longterm physical and neurologic development in newborn infants with isolated single umbilical artery. Am J Obstet Gynecol. 2010;203(4):368.e1-7.

11. Hua M, Odibo AO, Macones GA, Roehl KA, Crane JP, Cahill AG. Single umbilical artery and its associated findings. Obstet Gynecol. 2010;115(5):930 -4 .

12. Murphy-Kaulbeck L, Dodds L, Joseph KS, Van den Hof M. Single umbilical artery risk factors and pregnancy outcomes. Obstet Gynecol. 2010;116(4):843 -50 .

13. Predanic M, Perni SC, Friedman A, Chervenak FA, Chasen ST. Fetal growth assessment and neonatal birth weight in fetuses with an isolated single umbilical artery. Obstet Gynecol. 2005;105(5 Pt 1):1093-7.

14. Bombrys AE, Neiger R, Hawkins S, Sonek J, Croom C, McKenna D, et al Pregnancy outcome in isolated single umbilical artery. Am J Perinatol. 2008;25(4):239-42

15. Horton AL, Barroilhet L, Wolfe HM. Perinatal outcomes in isolated single umbilical artery. Am J Perinatol. 2010;27(4):321-4.

16. Alexander GR, Kogan M, Martin J, Papiernik E. What are the fetal growth patterns of singletons, twins, and triplets in the United States? Clin Obstet Gynecol. 1998;41(1):114-25

17. Wiegand S, McKenna DS, Croom C, Ventolini G, Sonek JD, Neiger R. Seria sonographic growth assessment in pregnancies complicated by an isolated single umbilical artery. Am J Perinatol. 2008;25(3):149-52.

18. Bugatto F, Quintero-Prado R, Melero-Jiménez V, Fajardo-Expósito MA Hervías-Vivancos B, Bartha JL. Ultrasound predictors of birth weight in euploid fetuses with isolated single umbilical artery. Ultrasound Obstet Gynecol. 2010;36(6):724-7.

19. Jiang Y, Li XH, Yang TZ. The impact of different sides of the absent umbilical artery on fetal growth in an isolated single umbilical artery. Arch Gynecol Obstet. 2013;288(3):531-6.

20. Catanzarite VA, Hendricks SK, Maida C, Westbrook C, Cousins L, Schrimmer D. Prenatal diagnosis of the two-vessel cord: implications for patient counselling and obstetric management. Ultrasound Obstet Gynecol. 1995;5(2):98-105.

21. Parilla BV, Tamura RK, MacGregor SN, Geibel LJ, Sabbagha RE. The clinical significance of a single umbilical artery as an isolated finding on prenatal ultrasound. Obstet Gynecol. 1995;85(4):570-2.

22. Geipel A, Germer U, Welp T, Schwinger E, Gembruch U. Prenatal diagnosis of single umbilical artery: determination of the absent side, associated anomalies, Doppler findings and perinatal outcome. Ultrasound Obstet Gynecol. 2000;15(2):114-7.

23. Rinehart BK, Terrone DA, Taylor CW, Isler CM, Larmon JE, Roberts WE. Single umbilical artery is associated with an increased incidence of structural and chromosomal anomalies and growth restriction. Am J Perinatol. 2000;17(5):229-32

24. Bryan EM, Kohler HG. The missing umbilical artery. I. Prospective study based on a maternity unit. Arch Dis Child. 1974;49(11):844-52. 